Article

\title{
Fungal and Bacterial Communities Exhibit Consistent Responses to Reversal of Soil Acidification and Phosphorus Limitation over Time
}

\author{
Sarah R. Carrino-Kyker ${ }^{1,2, *,+}$, Kaitlin P. Coyle ${ }^{2,3,+, \ddagger}$, Laurel A. Kluber ${ }^{1,2, \S}$ and David J. Burke ${ }^{1,2}$ \\ 1 The Holden Arboretum, Kirtland, OH 44094, USA; laurel.kluber@gmail.com (L.A.K.); \\ dburke@holdenfg.org (D.J.B.) \\ 2 Department of Biology, Case Western Reserve University, Cleveland, OH 44106, USA; kate.coyle@ncsu.edu \\ 3 Department of Biological Sciences, North Carolina State University, Raleigh, NC 27695, USA \\ * Correspondence: skyker@holdenfg.org; Tel.: +1-440-946-4400 \\ + These authors contributed equally on this work. \\ $\ddagger \quad$ Present addresses: Q2 Solutions, Raleigh, NC 27560, USA. \\ $\S$ Present addresses: Novozymes, Salem, VA 24153, USA.
}

Received: 20 November 2019; Accepted: 11 December 2019; Published: 18 December 2019

\begin{abstract}
Chronic acid deposition affects many temperate hardwood forests of the northeastern United States, reduces soil $\mathrm{pH}$ and phosphorus (P) availability, and can alter the structure and function of soil microbial communities. The strategies that microorganisms possess for survival in acidic, low $\mathrm{P}$ soil come at a carbon (C) cost. Thus, how microbial communities respond to soil acidification in forests may be influenced by plant phenological stage as $\mathrm{C}$ allocation belowground varies; however, this remains largely unexplored. In this study, we examined microbial communities in an ecosystem level manipulative experiment where $\mathrm{pH}$ and/or $\mathrm{P}$ availability were elevated in three separate forests in Northeastern Ohio. Tag-encoded pyrosequencing was used to examine bacterial and fungal community structure at five time points across one year corresponding to plant phenological stages. We found significant effects of $\mathrm{pH}$ treatment and time on fungal and bacterial communities in soil. However, we found no interaction between $\mathrm{pH}$ treatment and time of sampling for fungal communities and only a weak interaction between $\mathrm{pH}$ elevation and time for bacterial communities, suggesting that microbial community responses to soil $\mathrm{pH}$ are largely independent of plant phenological stage. In addition, fungal communities were structured largely by site, suggesting that fungi were responding to differences between the forests, such as plant community differences.
\end{abstract}

Keywords: bacteria; fungi; $\mathrm{pH}$; community structure; 454 sequencing

\section{Introduction}

Forests are an important terrestrial biome, covering 30\% of Earth's surface and harboring a large percentage of the planet's plant and animal species [1]. In addition to providing $49 \%$ of terrestrial primary productivity [1], forests also provide important ecosystem services and sequester large amounts of carbon (C) in living biomass [2,3], which can offset the effects of anthropogenic emissions on global atmospheric $\mathrm{CO}_{2}$ levels and impact global climate change. Despite their importance, forest function is affected by human disturbance, such as landscape fragmentation, overharvesting, and atmospheric air pollution, including acid deposition [4-7]. Although forest cover has expanded in eastern North America over the last 75 years [8], these forests have developed, and persist, with high levels of acid deposition and the wet and dry deposition of nitrous oxide and sulfur oxide [9]. In fact, there is considerable evidence suggesting that many forests have undergone significant soil acidification since the middle of the 20th century $[7,9]$. Forest acidification is of particular interest as it 
can affect the availability of soil phosphorus $(\mathrm{P})$, an essential nutrient that can limit both plant and microbial growth [10]. When soil pH falls below 5, aluminum (Al) is mobilized from soil and can chemically bind to inorganic $\mathrm{P}\left(\mathrm{P}_{\mathrm{i}}\right)$, making $\mathrm{P}_{\mathrm{i}}$ generally unavailable for uptake by plants and soil microbes [11].

When soils are acidic, microorganisms elicit a physiological response to cope with the surrounding low $\mathrm{pH}$ environment. Such responses include producing membrane proteins and fatty acids for protection from the external environment, producing buffer molecules to maintain internal $\mathrm{pH}$, or through active pumping of hydrogen ions to maintain the proton motive force of the cell membrane [12, 13]. In addition to these physiological responses to acidic soil $\mathrm{pH}$, when soils are below a $\mathrm{pH}$ of 5 , microorganisms are also faced with low soil $\mathrm{P}_{\mathrm{i}}$ due to mobilized $\mathrm{Al}$ (as described above). Soil microbes can compensate for the limited availability of $\mathrm{P}_{\mathrm{i}}$ by acquiring more $\mathrm{P}$ from organic sources $\left(\mathrm{P}_{\mathrm{o}}\right)$ through the production of phosphatases or by producing organic acids that liberate $P_{i}$ from metal complexes [14-16]. However, the production of cellular molecules necessary for survival under acidic soil $\mathrm{pH}$ and low $\mathrm{P}$ availability come at an energetic and $\mathrm{C}$ cost to the microbes (e.g., see [17]). Soil $\mathrm{pH}$ and $\mathrm{P}$ availability are known to have large impacts on soil microbial communities, including community structure (e.g., [18-23]). Indeed, the large body of literature correlating soil pH with soil fungal and bacterial community structure, diversity, and biomass (e.g., [21,23-25]) suggests that soil $\mathrm{pH}$ may be the primary factor influencing community changes in a variety of ecosystems. Besides community structure changes, reductions in microbial biomass or respiration have been found in soils with acidic $\mathrm{pH}$ [26] or limited $\mathrm{P}$ availability [27,28]. It is plausible, and we have previously suggested [26], that these changes to microbial community structure and microbial biomass reflect an energetic and $\mathrm{C}$ cost associated with survival in low $\mathrm{pH}$ and low $\mathrm{P}$ soils.

The flow of photosynthetic $C$ from temperate forest plants to soil microorganisms changes over the course of a calendar year as plant phenological stages change. During the growing season, plants actively transfer $\mathrm{C}$ to roots and rhizosphere soil in the form of relatively labile root extracts, while during the dormant season when plants are not actively fixing $C$, microbial communities become more dependent on recalcitrant forms of $C$ present in litter and organic matter [29,30]. Such changes in labile $C$ input from plants can have large effects on soil microbial activities [31]. As described above, we have previously found community changes when soil $\mathrm{pH}$ and soil $\mathrm{P}$ were experimentally elevated for mycorrhizal and root-associated fungi on mature tree roots $[20,26]$, but these investigations were conducted only during the growing season in late summer. It is plausible that the availability of soil C over time (i.e., growing season compared to dormant season) may interact with the response (i.e., community structure change) of soil microorganisms to soil acidification and P limitation. However, the response of microbial communities to soil $\mathrm{pH}$ and $\mathrm{P}$ availability in conjunction with changes to plant phenological stage has been largely unexplored.

Here we describe a study that examined the microbial community response to soil acidification and $\mathrm{P}$ limitation over one calendar year within an ecosystem level manipulative experiment in northeastern Ohio. Within each plot, the soil was amended such that it had elevated $\mathrm{pH}$, elevated $\mathrm{P}$, elevated $\mathrm{pH}$ $+\mathrm{P}$, or was an untreated control $[20,26,32]$. We used 454 sequencing to examine the response of soil fungal and bacterial communities to altered soil chemistry over five sampling times corresponding to annual plant phenological stages. We hypothesized that: (1) bacterial and fungal communities would be affected by changes to soil $P_{i}$ during the growing season since $P_{i}$ is expected to limit microbial activity and growth while labile $C$ availability is high; and (2) since fungi are the primary decomposers in temperate forests [33], fungal communities would respond strongly to $P_{i}$ limitation during the dormant season when $\mathrm{pH}$ and $\mathrm{P}_{\mathrm{i}}$ could create a dual limitation $(\mathrm{P}$ and $\mathrm{C}$ ) during a time of high decomposition activity. 


\section{Materials and Methods}

\subsection{Site Description}

Our experiment consisted of 36 experimental plots (measuring $20 \mathrm{~m} \times 40 \mathrm{~m} ; 800 \mathrm{~m}^{2}$ ) that were located in three mature temperate deciduous forests within Northeastern Ohio, USA. The 36 plots were located in two forest stands at The Holden Arboretum (Kirtland, Ohio) and one forest stand at Squire Valleevue and Valley Ridge Farms (Case Western Reserve University, Hunting Valley, Ohio), with 12 plots per forest. Forests are dominated by oak (Quercus spp.), maple (Acer spp.), and American beech (Fagus grandifolia) trees. This region has an average temperature of $8.1^{\circ} \mathrm{C}$, an average of $120 \mathrm{~cm}$ of precipitation and soils are loamy to silty loams with an average soil $\mathrm{pH}$ of 4.3 for glaciated forests. Additional description of the plots can be found in DeForest et al. [32].

\subsection{Experimental Design}

Beginning in the autumn of 2009, treated plots received either a direct application of crushed limestone (Hi-Ca lime; high calcium to magnesium ratio) to increase soil $\mathrm{pH}$ or triple super phosphate (TSP) to elevate soil $\mathrm{P}_{\mathrm{i}}$ availability, or both in combination for an elevated $\mathrm{pH}+\mathrm{P}$ treatment. The elevated $\mathrm{pH}$ and elevated $\mathrm{pH}+\mathrm{P}$ plots initially received $11.4 \mathrm{mg} \mathrm{ha}^{-1}$ of $\mathrm{Hi}-\mathrm{Ca}$ lime (The Andersons, Maumee, $\mathrm{OH}, \mathrm{USA}$ ) in an effort to raise soil $\mathrm{pH}$ to within a range of 5.8 to 6.2 for the top $5 \mathrm{~cm}$. This target $\mathrm{pH}$ was chosen because exchangeable aluminum is immobilized within this soil $\mathrm{pH}$ range. Additional lime applications were made in the fall of 2010 to maintain the target soil pH. To increase P availability, the elevated $\mathrm{P}$ and elevated $\mathrm{pH}+\mathrm{P}$ plots received approximately $42 \mathrm{~kg} \mathrm{P} \mathrm{ha}^{-1}$ in 2010 prior to our sampling and an additional $34 \mathrm{~kg} \mathrm{P} \mathrm{ha}^{-1}$ in spring 2011 (following our spring sampling, but prior to our early summer sampling; see below) as TSP (The Andersons, Maumee, OH, USA). Treatments effectively raised soil $\mathrm{pH}$ by approximately 1.5 units and available $\mathrm{P}_{\mathrm{i}}$ (i.e., resin $\mathrm{P}$ ) by approximately 6-fold (see $[20,26]$ for detailed soil chemistry data collected at the start and end of the sampling described here, respectively).

\subsection{Soil Sampling}

Soils were collected from each of the 36 plots at five time points within a calendar year for a total of 180 samples (Figure 1). The collections were made in November 2010 (in fall; after trees dropped their leaves), February 2011 (winter), May 2011 (spring; after tree leaf out), July 2011 (early summer), and September 2011 (late summer). These time points were chosen because they corresponded with distinct stages of tree phenology, including leaf out and litter fall, and should reflect changes in microbial resource availability (i.e., C) over the year. At each time point, 15 soil cores $(2.5 \mathrm{~cm}$ diameter, $5 \mathrm{~cm}$ depth) were randomly sampled within each plot, pooled, sieved to $2 \mathrm{~mm}$, and stored at $-70{ }^{\circ} \mathrm{C}$ until used for DNA extraction.

\subsection{DNA Extraction}

DNA was extracted from approximately $0.5 \mathrm{~g}$ of soil for each of the 180 samples using a standard phenol/chloroform extraction procedure described in Burke et al. [18]. DNA was quantified using a NanoDrop spectrophotometer (Thermo Fisher Scientific, Waltham, MA, USA) and, for each time point, the three treatment replicates per forest were pooled on an equimolar basis for a final template concentration of $25 \mathrm{ng} / \mu \mathrm{L}$. This resulted in a total of 60 DNA samples (12 for each time point; Figure 1). 


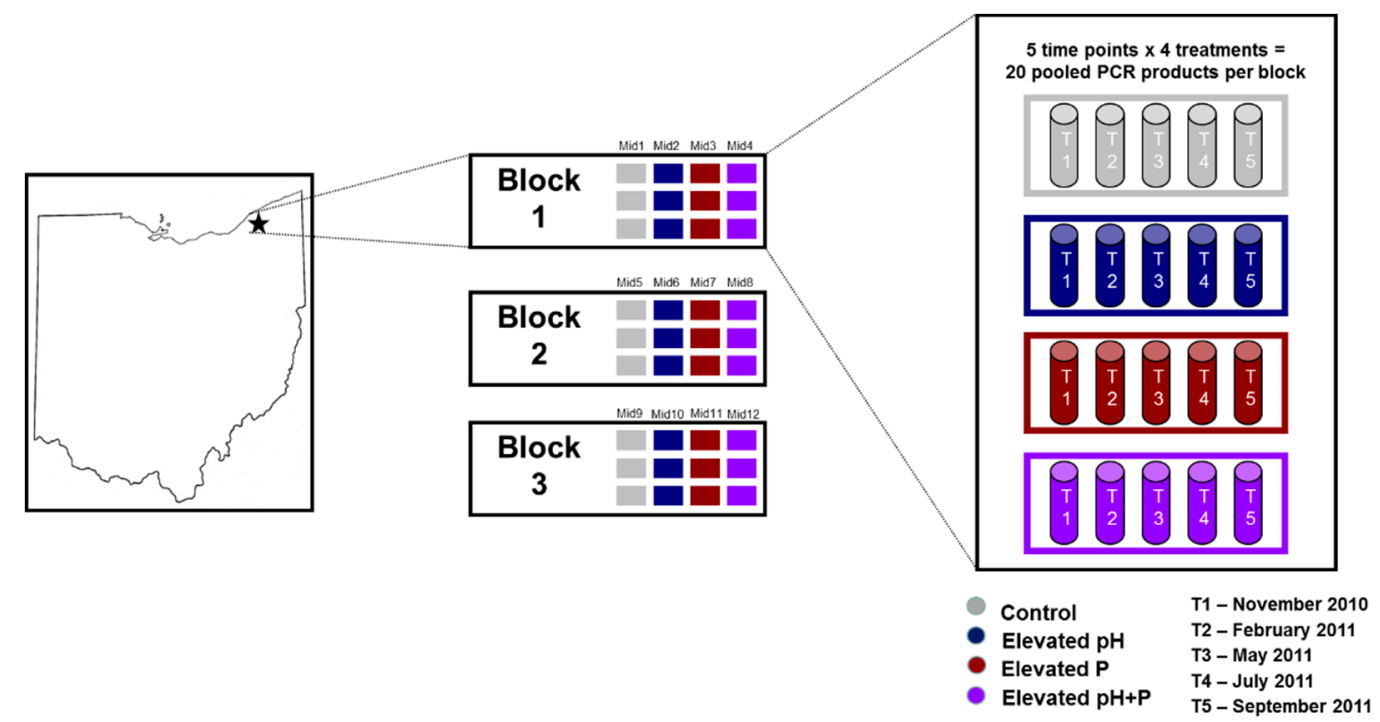

Figure 1. Diagram of the study design, which indicates the three forest blocks. Within each forest block were twelve plots (three of each treatment; shown in different colors) for a total of 36 plots. Soil from each plot was sampled five times throughout a calendar year (indicated as T1-T5) for a total of 180 soil samples that were used for DNA extraction. The DNA was then pooled within each treatment of each block for 20 DNA samples per block (a schematic of the DNA samples for one block is shown) and 60 DNA samples total that were sequenced. MID = multiplexing identifier.

\section{5. $P C R$}

The fungal community was analyzed by PCR amplification of the internal transcribed spacer (ITS)1 region of the rRNA gene using the forward primer ITS1-F (CTTGGTCATTTAGAGGAAGTAA) [34] and the reverse primer ITS2 (GCTGCGTTCTTCATCGATGC) [35], which have been proven effective in previous pyrosequencing studies of fungal diversity in forest soils [36]. Attached to the ITS1-F primer were multiplexing identifiers (MIDs) to allow for separation of sequence reads into treatment $x$ forest combinations. A total of 12 MIDs were used and were consistently assigned to a treatment/forest DNA extract across time points. Each primer also had a Genome Sequencer (GS) FLX Titanium Primer attached to allow for sequencing with primer $\mathrm{A}$ attached to the forward and primer $\mathrm{B}$ attached to the reverse. For the fungal PCRs, each $25 \mu \mathrm{L}$ reaction contained $22.5 \mu \mathrm{L}$ Platinum ${ }^{\circledR}$ PCR SuperMix High Fidelity (Thermo Fisher Scientific), $1 \mu \mathrm{L}$ template, $0.4 \mu \mathrm{g} / \mu \mathrm{L}$ bovine serum albumin, and $0.1 \mu \mathrm{M}$ of each primer. Thermocycling conditions were $3 \mathrm{~min}$ at $94^{\circ} \mathrm{C}$, followed by 33 cycles of $94{ }^{\circ} \mathrm{C}$ for $45 \mathrm{~s}, 50^{\circ} \mathrm{C}$ for $30 \mathrm{~s}$, and $72{ }^{\circ} \mathrm{C}$ for $60 \mathrm{~s}$, with a final extension of $72{ }^{\circ} \mathrm{C}$ for $10 \mathrm{~min}$. For bacterial community structure analysis, the $16 \mathrm{~S}$ gene was PCR-amplified with the primer set 27F (AGAGTTTGATCCTGGCTCAG) and 338R (TGCTGCCTCCCGTAGGAGT) [37] with the GLS FLX Titanium Primer A and Primer B, respectively, attached to allow for sequencing and MIDs also attached to the 338R primer to allow for separation into treatment $\times$ forest combinations as described above. The $25 \mu \mathrm{L}$ bacterial PCR reactions contained $17.5 \mu \mathrm{L}$ Platinum ${ }^{\circledR}$ PCR SuperMix High Fidelity, $1 \mu \mathrm{L}$ template, $0.5 \mu \mathrm{g} / \mu \mathrm{L}$ bovine serum albumin, and $0.1 \mu \mathrm{M}$ of each primer and thermocycling conditions were $3 \mathrm{~min}$ at $94^{\circ} \mathrm{C}$, followed by 30 cycles of $94{ }^{\circ} \mathrm{C}$ for $45 \mathrm{~s}, 50{ }^{\circ} \mathrm{C}$ for $30 \mathrm{~s}$, and $72{ }^{\circ} \mathrm{C}$ for $60 \mathrm{~s}$, with a final extension of $72{ }^{\circ} \mathrm{C}$ for $10 \mathrm{~min}$. This resulted in 120 fungal PCR products and 120 bacterial PCR products. Bacterial and fungal PCR products were combined at a 3:1 bacterial:fungal ratio to account for greater bacterial abundance while allowing all PCR products to be run on the same 454 sequencing plate.

\subsection{Sequencing}

Sequencing was completed on the Genome Sequencer FLX 454 System through Case Western Reserve University's Genomics Core with each of the five time points run on a separate 1/8 section of 
the plate. This allowed for separation between the time points, while the 12 MIDs used during PCR allowed for separation of the treatment $\times$ forest combinations.

\subsection{Sequence Analysis}

Sequences were demultiplexed using Galaxy with usegalaxy.org [38-40] where primer sequences were used to separate fungal and bacterial sequences and MIDs were used to separate the different treatment $\times$ forest samples. Following demultiplexing, fungal and bacterial sequence reads were analyzed within the UPARSE pipeline [41]. The USEARCH software [42] was used to trim sequences to a fixed base pair length to allow for global alignment; fungal sequences were trimmed to $200 \mathrm{bp}$ and bacterial sequences were trimmed to $250 \mathrm{bp}$. Sequences were filtered for quality with the maximum expected error parameter (fastq_maxee) set to 3 . The "sortbysize" command was used to remove singletons (i.e., sequences that occurred only once) and the "cluster_otus" command was used for operational taxonomic unit (OTU) clustering at $97 \%$ similarity with the UCLUST algorithm [42]. Chimeras were removed with reference-based chimera filtering using the UCHIME algorithm [43] and screening against the UNITE database [44,45] for fungi and the Genomes OnLine Database (GOLD) database [46] for bacteria. Taxonomy was assigned within the assign_taxonomy.py command of the Quantitative Insights Into Microbial Ecology (QIIME) pipeline [47] with Basic Local Alignment Search Tool (BLAST) comparisons [48] to the UNITE database [44,45] for fungi and UCLUST comparisons [42] to the GreenGenes database [49,50] for bacteria. Finally, OTUs containing only one sequence read (i.e., singletons) were removed from the dataset, as such OTUs can represent sequencing errors [51]. Sequences are publicly available through the Sequence Read Archive at the National Center for Biotechnology Information (NCBI) site under BioProject number PRJNA377728 and BioSample numbers SAMN06471527 through SAMN06471531.

\subsection{Statistical Analysis}

Matrices of fungal and bacterial OTUs were further processed by removing OTUs that were found in only one sample and OTUs that did not have meaningful taxonomic matches (i.e., the pipeline returned the taxonomic identity as "unassigned" or "no blast hit" and no domain match, as well as the bacterial OTU that matched with "chloroplast"). While this can potentially remove rare taxa, it also removed OTUs that are potential sequencing errors and non-target OTUs that did not match at a domain level with Bacteria or at a kingdom level with Fungi. A total of 13,592 fungal sequence reads and 80,854 bacterial sequence reads representing 573 fungal and 1967 bacterial OTUs met our quality control parameters and were used for statistical analysis. To compare fungal and bacterial communities among treatments and across time points, nonparametric permutation procedure (PERMANOVA) and principle components analysis (PCoA) were conducted using the adonis and betadisper commands, respectively, in the vegan package (v2.5.5) [52] of $R$ (v3.5.3) [53]. Both PERMANOVA and PCoA analyses used the Bray-Curtis distance measure. Sequence counts were normalized with the trimmed mean of M (TMM) method of the edgeR package (v3.18.1) [54,55] prior to statistical analyses, which has shown to be a useful method for comparing sequencing libraries of varying size [56]. In order to visualize changes in taxa between treatments and time points, heat maps were made with the Heatplus package (v2.28.0) [57], also in R. Dendrograms associated with the heat maps used the Bray-Curtis distance measure (calculated in the vegan package) to cluster samples and included OTUs that had at least one instance of $1 \%$ relative abundance for bacterial taxa and $2 \%$ relative abundance for fungal taxa. To further analyze fungal communities, fungal OTUs were also parsed into functional guilds based on their taxonomic assignment using FUNGuild (v1.0) [58]. Only guild assignments that had confidence rankings of "highly probable" and "probable" were included in statistical analysis and the dataset was further subset into guilds that included "Plant Pathogen", "Ectomycorrhizal", "Saprotroph", and "Ericoid mycorrhizal" according to FUNGuild. Linear mixed effect models were used to test for differences in the relative sequence abundance of bacterial taxa and functional guilds between treatments and sampling time points using the lme command in the $\mathrm{R}$ 
package nlme (v3.1.137) [59], where forest block was used as the random effect. To test for differences between the individual treatments (control, elevated $\mathrm{pH}$, elevated $\mathrm{P}$, and elevated $\mathrm{pH}+\mathrm{P}$ ) and time points, multiple comparisons were calculated with the glht command in the multcomp package of $\mathrm{R}$ (v1.4.10) [60]. Graphs were made using ggplot2 (v3.2.1) [61] in R.

\section{Results}

\subsection{Bacterial Community Structure}

PERMANOVA results indicated that bacterial communities were significantly affected by $\mathrm{pH}$ treatment and time of sampling (Table 1). PCoA showed clear shifts in bacterial community structure over time, as well as between elevated and ambient soil $\mathrm{pH}$ conditions (Figure 2). The bacterial taxa that shifted with $\mathrm{pH}$ elevation were dependent on the time of sampling, as shown by the dendrogram on the bacterial heat map (Figure 3). Two clusters of elevated $\mathrm{pH}$ samples were apparent; the top cluster (shown in maroon) included samples collected largely in July, but also in May and November, while the bottom cluster (shown in light blue) included samples collected only in September (Figure 3). In general, elevated $\mathrm{pH}$ plots in September had higher relative sequence numbers for the genus Rhodoplanes, while elevated $\mathrm{pH}$ plots in July and November had higher relative sequence numbers for the genus Bradyrhizobium compared to ambient $\mathrm{pH}$ plots (Figure 3). Sequences matching the order Ellin6519 (phylum Acidobacteria) were relatively higher in elevated $\mathrm{pH}$ plots in September, but relatively lower in elevated $\mathrm{pH}$ plots in July compared to other time points (Figure 3). OTUs that matched with the family Koribacteraceae were generally in lower relative abundance for both elevated $\mathrm{pH}$ dendrogam clusters compared to the cluster with all ambient $\mathrm{pH}$ samples (shown in green; Figure 3). OTUs that matched with the family Acidobacteriaceae were generally in higher relative abundance for the middle cluster, which contained all ambient $\mathrm{pH}$ plots.

Table 1. Three-way nonparametric permutation procedure (PERMANOVA) showing the effects of $\mathrm{pH}$ treatment, phosphorus (P) treatment, and time of sampling, along with the interactions, on soil bacterial community structure. The samples were blocked by forest using the strata option.

\begin{tabular}{ccccccc}
\hline & $\mathbf{d f}^{\dagger}$ & $\mathbf{S S}^{\dagger}$ & Mean Sqs $^{\dagger}$ & $\boldsymbol{F}$-Value & $\mathbf{R}^{\mathbf{2}}$ & $p$-Value \\
\hline pH & 1 & 0.51 & 0.51 & 3.99 & 0.048 & $<\mathbf{0 . 0 0 1}$ \\
P & 1 & 0.13 & 0.13 & 0.98 & 0.012 & 0.26 \\
Time & 4 & 3.46 & 0.87 & 6.78 & 0.33 & $<\mathbf{0 . 0 0 1}$ \\
pH:P & 1 & 0.15 & 0.15 & 1.17 & 0.014 & 0.14 \\
pH:Time & 4 & 0.56 & 0.14 & 1.10 & 0.053 & 0.098 \\
P:Time & 4 & 0.33 & 0.083 & 0.65 & 0.032 & 0.97 \\
pH:P:Time & 4 & 0.34 & 0.085 & 0.67 & 0.032 & 0.96 \\
Residuals & 80 & 5.11 & 0.13 & & 0.48 & \\
Total & 119 & 10.60 & & & 1 & \\
\hline
\end{tabular}

$+\overline{\text { df: degrees of freedom; SS: sequential sums of squares; Mean Sqs: mean squares. }{ }^{*} \text { Significant } p \text {-values at } \alpha=0.05}$ are in bold; $p$-values approaching significance at $\alpha=0.1$ are in italics. 


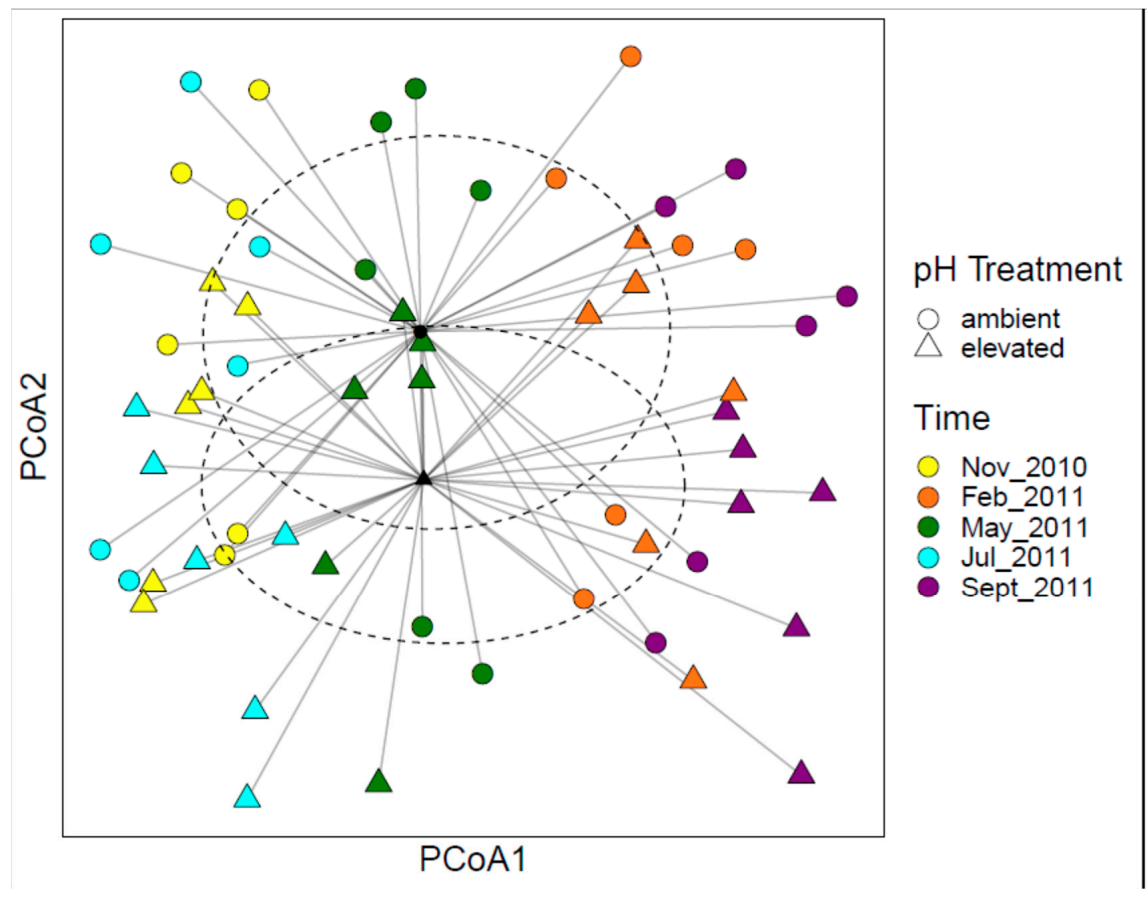

Figure 2. Principle component analysis (PCoA) ordination of the bacterial community structure changes between $\mathrm{pH}$ treatments and over time. Different colors represent different time points, while the shapes represent different $\mathrm{pH}$ treatments. Centroids and ellipses for the $\mathrm{pH}$ treatments are also shown.
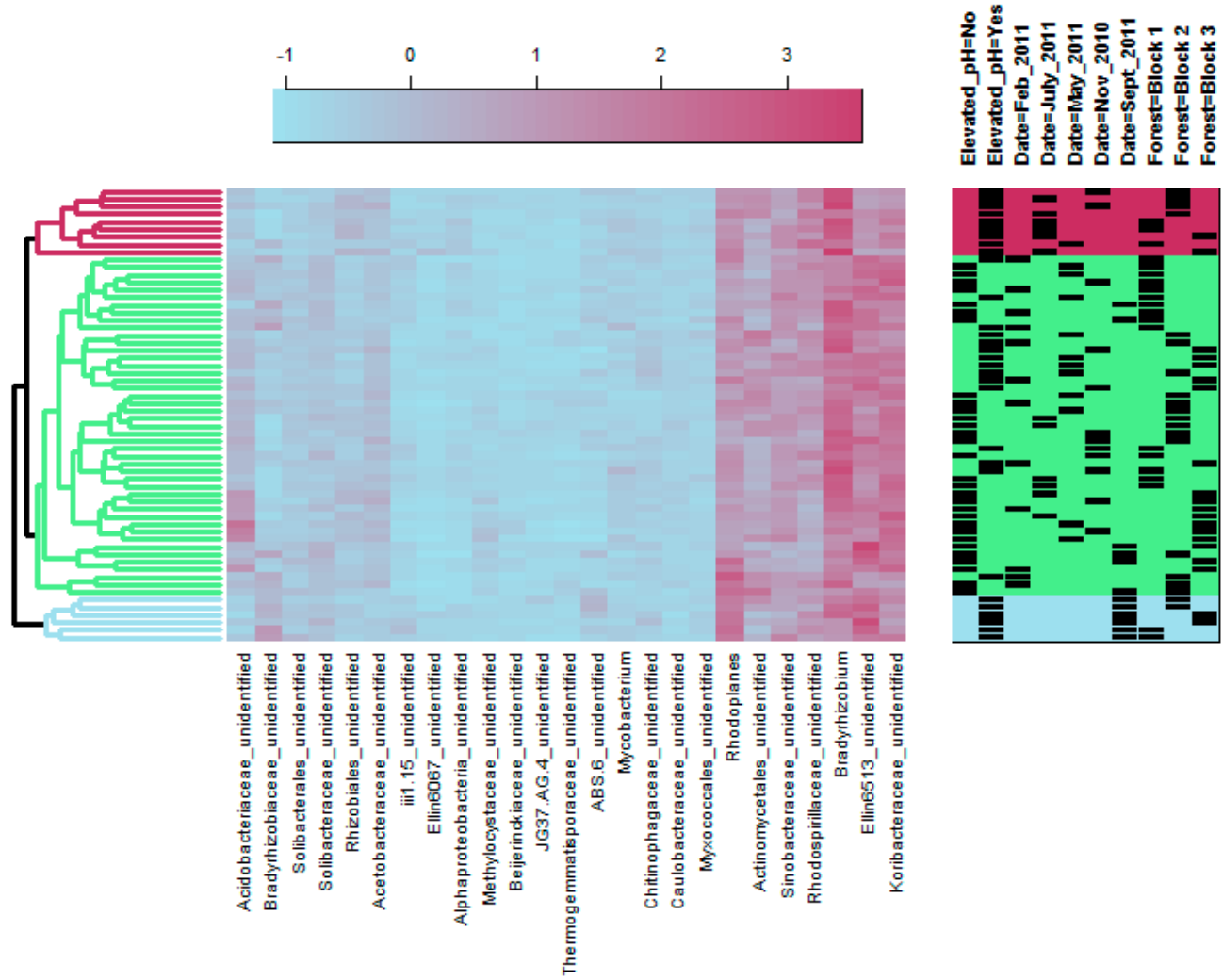

Figure 3. Heatmap of the bacterial taxa present at $2 \%$ relative abundance or above. Taxa were identified to genus if possible and then the lowest taxonomic rank available. Three clusters of samples were found based on bacterial taxa and are shown in three colors. Treatments, time points, and forest blocks are indicated by the shaded rectangles on the right. The scale of the color legend is log base 10 of the numbers shown. 


\subsection{Fungal Community Structure}

Similar to the bacterial community results, PERMANOVA on the fungal community structure indicated that fungal communities were significantly affected by $\mathrm{pH}$ treatment and time of sampling (Table 2). However, PCoA showed samples clustering in ordination space mostly by forest block, suggesting that fungal community changes were largely driven by the location of sampling (Figure 4). Separation between elevated $\mathrm{pH}$ (triangles) and ambient $\mathrm{pH}$ (circles) were generally apparent for each forest block (Figure 4), which confirms the significant effect of $\mathrm{pH}$ treatment on fungal community structure with PERMANOVA. Because of the strong effect of location on fungal communities, taxonomic differences between soil treatments or over time were more nuanced (Figure 5). However, when fungal taxa were grouped by functional guild, differences in the relative abundance of saprotrophic fungi were apparent over time (Table 3, Figure 6A). In addition, significant interactions between $\mathrm{pH}$ and $\mathrm{P}$ elevation were found for the relative abundance of saprotrophic fungi and ericoid mycorrhizal fungi (Table 3), however, multiple comparisons showed no significant differences between the individual treatments (Figure 6B,C). The forest blocks differed in their relative abundance of saprotrophic fungi, ectomycorrhizal (ECM) fungi, and ericoid mycorrhizal (ERM) fungi (Figure S1). These differences in functional guilds may be driven by the dominant tree species, since the forest block with the lowest abundance of ectomycorrhizal fungal sequences is also the forest block with the highest number Acer trees (sugar maple and red maple), which form associations with arbuscular mycorrhizal fungi and could explain the lower abundance of the ectomycorrhizal and ericoid mycorrhizal functional guilds.

Table 2. Three-way nonparametric permutation procedure (PERMANOVA) showing the effects of $\mathrm{pH}$ treatment, $\mathrm{P}$ treatment, and time of sampling, along with their interactions, on soil fungal community structure. The samples were blocked by forest using the strata option.

\begin{tabular}{ccccccc}
\hline & $\mathbf{d f}^{\dagger}$ & $\mathbf{S S}^{\dagger}$ & Mean Sqs $^{\dagger}$ & $\boldsymbol{F}$-Value & $\mathbf{R}^{\mathbf{2}}$ & $p$-Value \\
\hline pH & 1 & 0.49 & 0.49 & 1.53 & 0.025 & $<\mathbf{0 . 0 0 1}$ \\
$\mathrm{P}$ & 1 & 0.28 & 0.28 & 0.87 & 0.014 & 0.27 \\
Time & 4 & 3.32 & 0.83 & 2.59 & 0.17 & $<\mathbf{0 . 0 0 1}$ \\
pH:P & 1 & 0.24 & 0.24 & 0.76 & 0.012 & 0.67 \\
pH:Time & 4 & 0.94 & 0.23 & 0.73 & 0.047 & 0.94 \\
P:Time & 4 & 0.86 & 0.21 & 0.67 & 0.043 & 1.00 \\
pH:P:Time & 4 & 0.82 & 0.20 & 0.64 & 0.041 & 0.99 \\
Residuals & 40 & 12.82 & 0.32 & & 0.65 & \\
Total & 59 & 19.77 & & & 1 & \\
\hline
\end{tabular}

$+\overline{\text { df: degrees of freedom; SS: sequential sums of squares; Mean Sqs: mean squares. }{ }^{*} \text { Significant } p \text {-values at } \alpha=0.05}$ are in bold. 


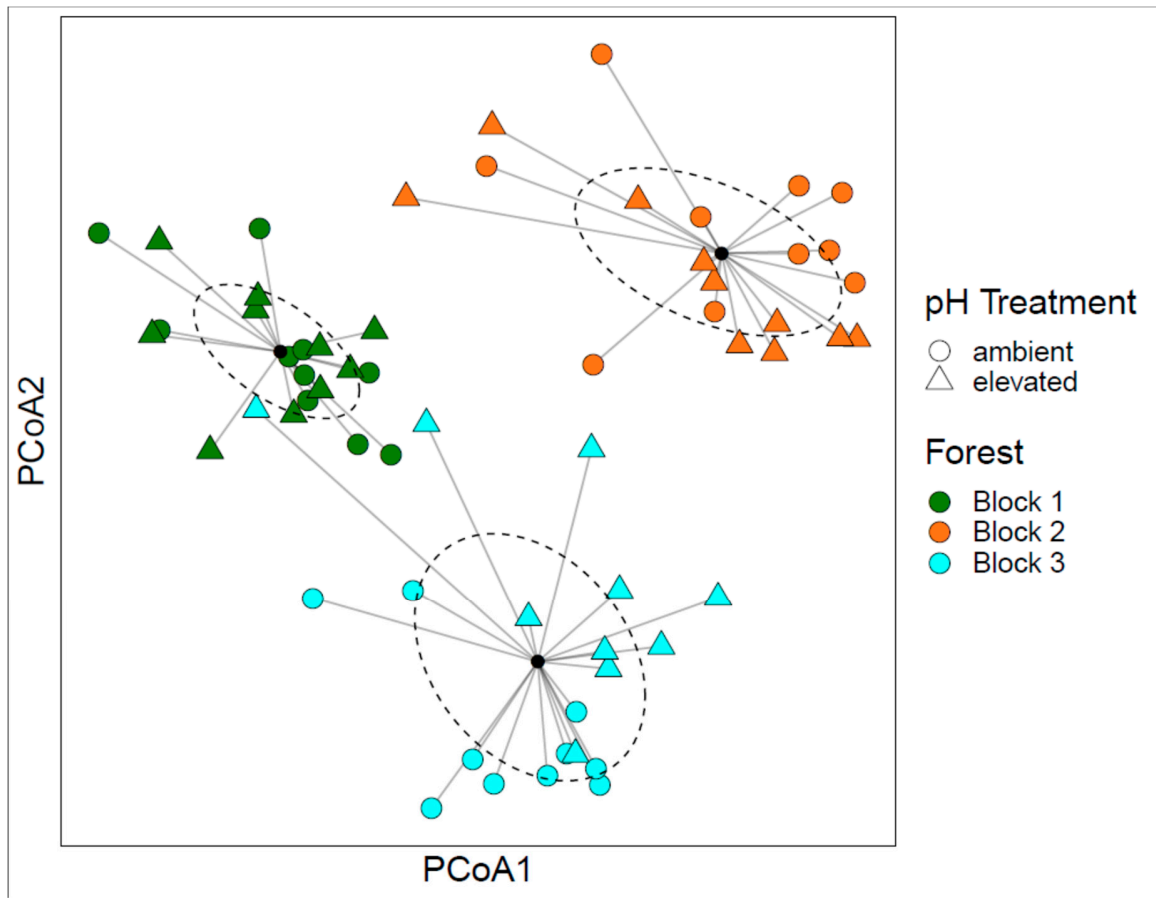

Figure 4. PCoA ordination of the fungal community structure changes between $\mathrm{pH}$ treatments and forest blocks. Different colors represent different forest blocks, while the shapes represent different $\mathrm{pH}$ treatments. Centroids and ellipses for the blocks are also shown.
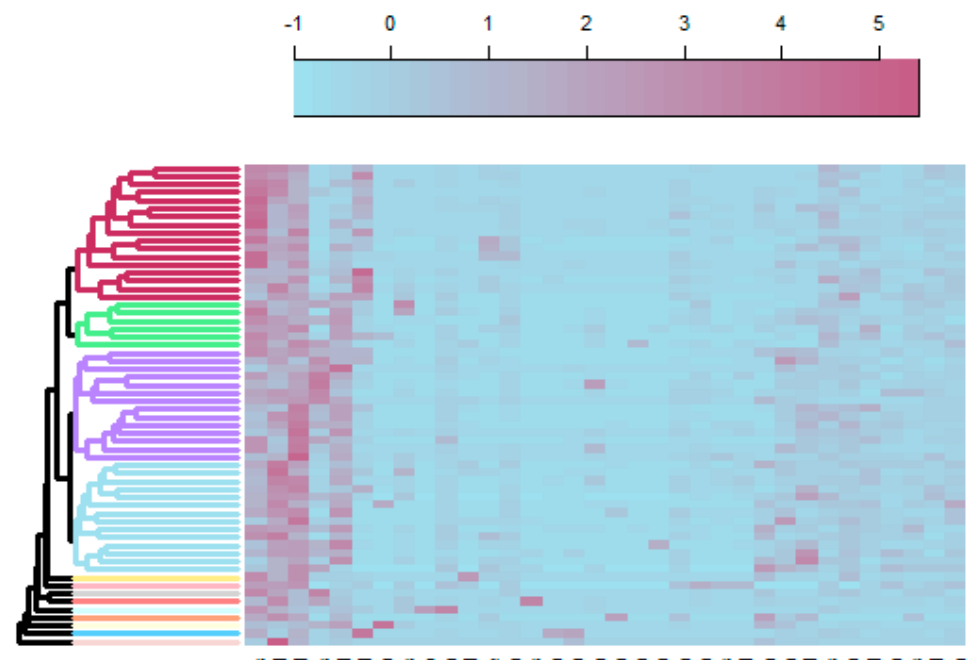
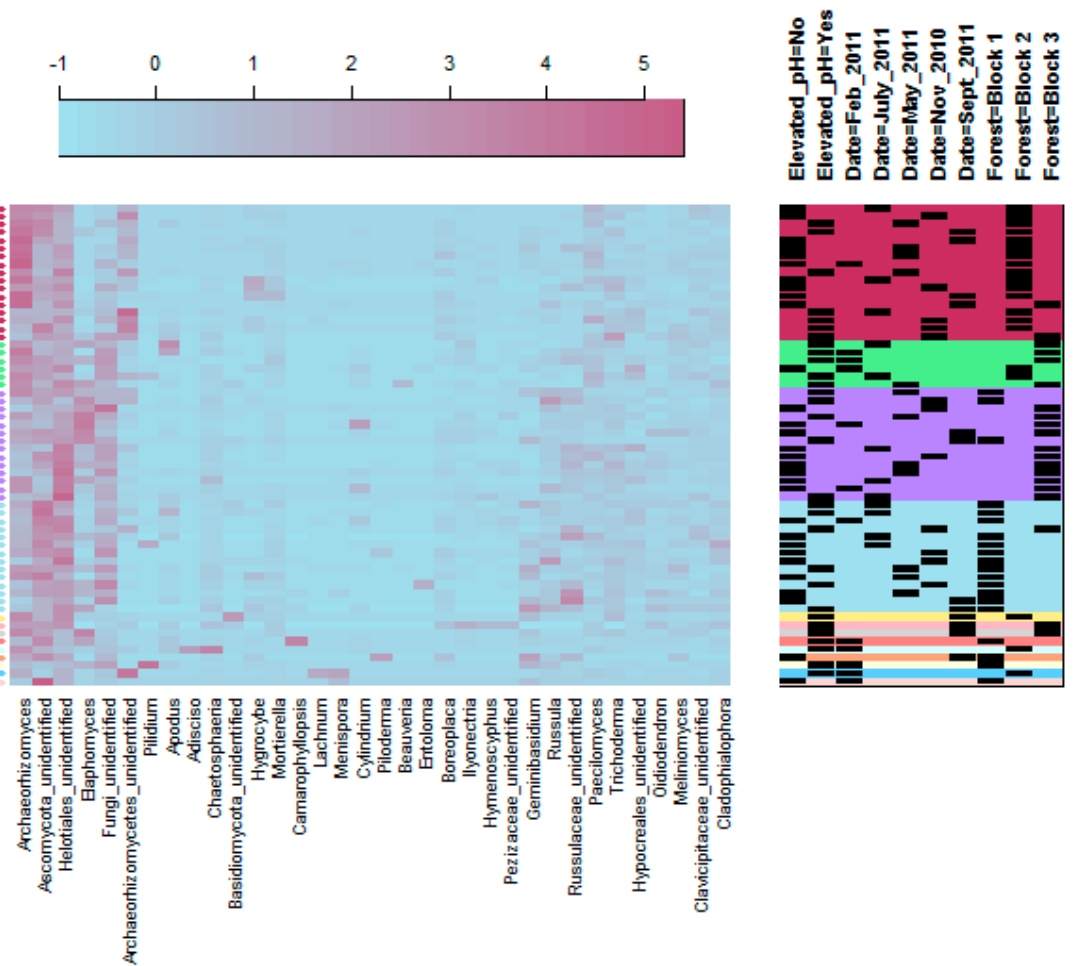

Figure 5. Heatmap of the fungal taxa present at 5\% relative abundance or above. Taxa were identified to genus if possible and then the lowest taxonomic rank available. Four main clusters of samples were found based on bacterial taxa and are shown in three colors. Treatments, time points, and forest blocks are indicated by the shaded rectangles on the right. The scale of the color legend is log base 10 of the numbers shown. 
Table 3. Linear mixed-effects models showing the effects of $\mathrm{pH}$ treatment, $\mathrm{P}$ treatment, and time of sampling, along with their interactions, on the relative sequence abundance of different fungal guilds. The forest blocks were the random effect in the models.

\begin{tabular}{|c|c|c|c|c|}
\hline & numDF $^{\dagger}$ & $\operatorname{denDF}^{\dagger}$ & $F$-Value & $p$-Value * \\
\hline \multicolumn{5}{|l|}{ Saprotroph } \\
\hline $\mathrm{pH}$ & 1 & 38 & 0.47 & 0.50 \\
\hline $\mathrm{P}$ & 1 & 38 & 0.019 & 0.89 \\
\hline Time & 4 & 38 & 6.57 & $<0.01$ \\
\hline pH:P & 1 & 38 & 5.02 & 0.031 \\
\hline pH:Time & 4 & 38 & 2.56 & 0.054 \\
\hline P:Time & 4 & 38 & 0.096 & 0.98 \\
\hline pH:P:Time & 4 & 38 & 1.38 & 0.26 \\
\hline \multicolumn{5}{|c|}{ Ericoid Mycorrhizal Fungi } \\
\hline $\mathrm{pH}$ & 1 & 37 & 0.012 & 0.91 \\
\hline $\mathrm{P}$ & 1 & 37 & 0.70 & 0.41 \\
\hline Time & 4 & 37 & 0.75 & 0.56 \\
\hline $\mathrm{pH}: \mathrm{P}$ & 1 & 37 & 4.71 & 0.036 \\
\hline pH:Time & 4 & 37 & 0.32 & 0.86 \\
\hline P:Time & 4 & 37 & 0.26 & 0.90 \\
\hline pH:P:Time & 4 & 37 & 0.90 & 0.47 \\
\hline \multicolumn{5}{|c|}{ Ectomycorrhizal Fungi } \\
\hline $\mathrm{pH}$ & 1 & 38 & 0.23 & 0.64 \\
\hline $\mathrm{P}$ & 1 & 38 & 0.80 & 0.38 \\
\hline Time & 4 & 38 & 1.46 & 0.23 \\
\hline pH:P & 1 & 38 & 0.026 & 0.87 \\
\hline pH:Time & 4 & 38 & 0.15 & 0.96 \\
\hline P:Time & 4 & 38 & 1.41 & 0.25 \\
\hline pH:P:Time & 4 & 38 & 0.67 & 0.62 \\
\hline \multicolumn{5}{|l|}{ Pathogen } \\
\hline $\mathrm{pH}$ & 1 & 36 & 0.0013 & 0.97 \\
\hline $\mathrm{P}$ & 1 & 36 & 0.85 & 0.36 \\
\hline Time & 4 & 36 & 1.49 & 0.23 \\
\hline pH:P & 1 & 36 & 2.24 & 0.14 \\
\hline pH:Time & 4 & 36 & 0.41 & 0.80 \\
\hline P:Time & 4 & 36 & 2.21 & 0.087 \\
\hline pH:P:Time & 4 & 36 & 0.77 & 0.55 \\
\hline
\end{tabular}

${ }^{+}$numDF: numerator degrees of freedom; denDF: denominator degrees of freedom. ${ }^{*}$ Significant $p$-values at $\alpha=0.05$ are in bold. 

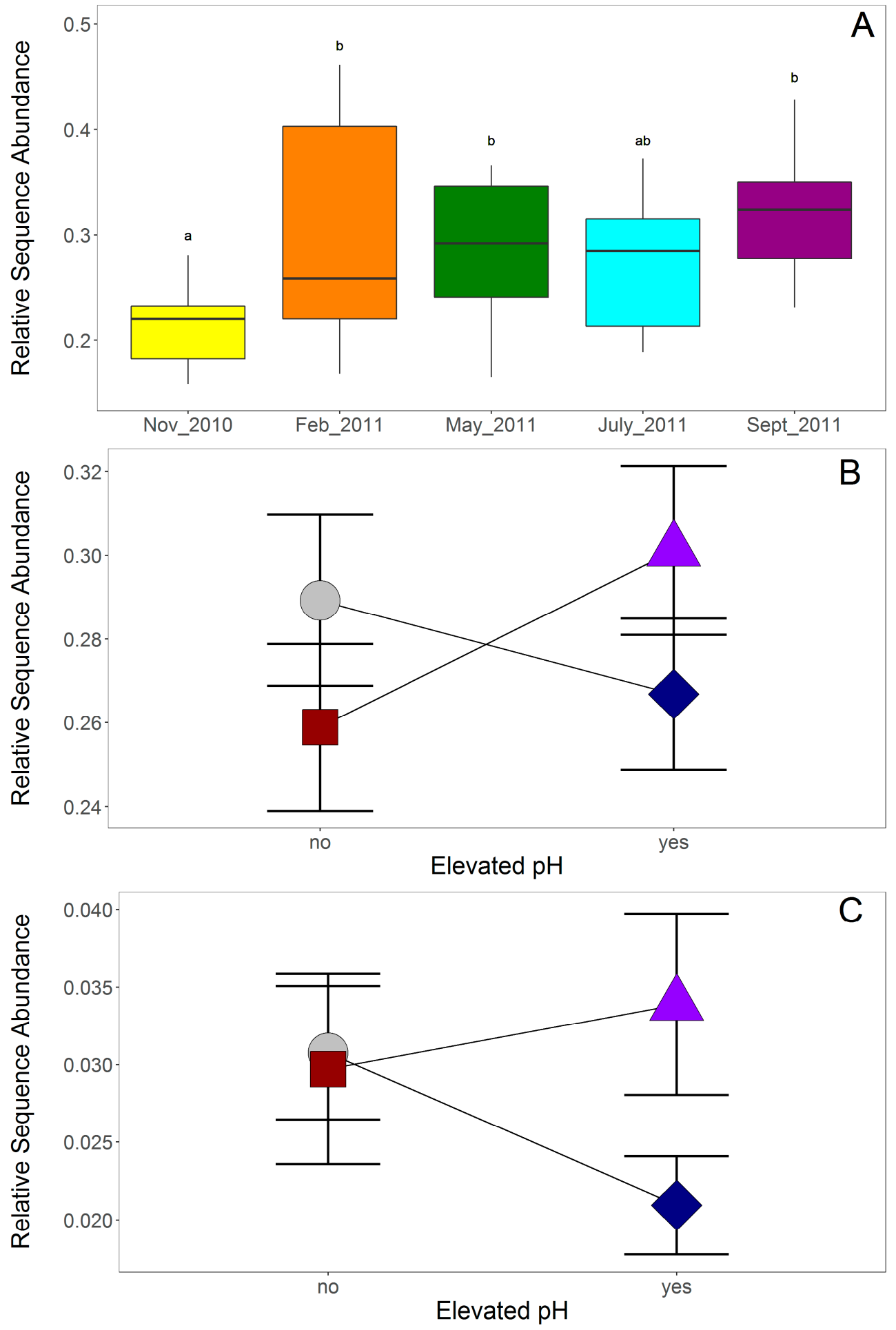

Figure 6. Relative sequence numbers for saprotrophic fungi and represented as (A) box and whisker plots at each collection time point or (B) mean \pm standard error for each treatment and (C) ericoid mycorrhizal fungi represented as mean \pm standard error for each treatment. For plot A, different letters denote time points that differed significantly. For plots B and C, treatments are represented by gray circles for Control, blue diamonds for Elevated $\mathrm{pH}$, red squares for Elevated $\mathrm{P}$, and purple triangles for Elevated $\mathrm{pH}+\mathrm{P}$ (colors are as in Figure 1). Elevated and ambient $\mathrm{pH}$ plots are separated along the $\mathrm{x}$-axis and lines connect elevated $\mathrm{P}$ plots and ambient $\mathrm{P}$ plots to each other to show the significant interaction. No letters are shown, as the treatments did not differ from one another significantly. 


\section{Discussion}

Contrary to our predictions, this study found little evidence to support our hypothesis that the microbial community response to soil $\mathrm{pH}$ and $\mathrm{P}_{\mathrm{i}}$ limitation would be altered by changes in plant phenological stage and the potential availability of labile $C$. Bacterial and fungal communities both demonstrated temporal variation, however the response of these communities to soil $\mathrm{pH}$ and $\mathrm{P}_{\mathrm{i}}$ availability were generally consistent over time, especially for soil fungi and with the exception of two bacterial genera in the Alphaproteobacteria family. Soil pH treatment altered both bacterial and fungal communities, while soil $\mathrm{P}_{\mathrm{i}}$ availability had no effect on either community.

The effects of $\mathrm{pH}$ on microbial community structure, diversity and richness has been established in a number of previous studies (e.g., [23,25]), although the cause of microbial response to pH cannot be easily determined. Because $\mathrm{pH}$ can have direct and indirect effects on soil microbes, their response to $\mathrm{pH}$ could reflect both a response to biochemical conditions in the surrounding soil [62] as well as biogeochemical processes that affect nutrient availability [63]. For example, changes in $\mathrm{pH}$ can affect nutrient and chemical availability, especially for $\mathrm{P}$ and $\mathrm{Al}$ which can interact to affect overall $\mathrm{P}$ nutrient availability [64]. The majority of microbes, though, have a $\mathrm{pH}$ range of only 2-3 units wide, above or below which they cannot survive $[62,65]$ and need to maintain cytoplasmic $\mathrm{pH}$ near an optimum for cell survival and activity [12]. It is, therefore, unsurprising that a change in $\mathrm{pH}$ of 2 units in the current study caused significant shifts in both fungal and bacterial communities.

\subsection{Fungal Community Response to pH Treatment}

In previous work, we found that elevating $\mathrm{pH}$ altered root-associated fungal communities and increased mycorrhizal colonization and fungal biomass in soil during the growing season [20,26]. Those results, along with the results of the current study, are in agreement with a large body of literature suggesting that $\mathrm{pH}$ has substantial effects on soil fungi [18,23,66-69]. In the present study, we found that changes to fungal communities with elevated $\mathrm{pH}$ are not restricted to the time of active plant growth but rather persist throughout the year. Although some authors have found evidence for increased turnover of mycorrhizal fungi under acidified conditions [70], our study found that temporal changes in fungal communities were similar in both ambient and elevated pH plots. This can be visualized by the fungal heat map (Figure 5), which shows the clusters comprised of samples from both $\mathrm{pH}$ treatments and all time points. Further, in the current study, the relative abundance of ECM fungal sequences did not differ significantly over time (Table 3), but saprotrophic fungal sequences did (Figure 6A). Abundance and biomass of saprotrophic fungi are known to vary as litter quality changes [71] and with invertebrate grazing [72]. As such, the temporal changes observed in the current study are to be expected for saprotrophic fungi. However, our study is contrary to many other studies which show significant temporal variation and high turnover for mycorrhizal fungal taxa [73]. The current study, though, examined bulk soil and not live root tips, which could explain this discrepancy. The soil samples we collected had between $1.9 \%$ and $36.5 \%$ ectomycorrhizal fungal sequences (an average of $13.6 \%$ ), while saprotrophic fungi were more abundant and comprised between $15.8 \%$ and $46.1 \%$ (an average of $27.9 \%$ ) of DNA sequences.

Fungal communities in the current study were structured more by the forest block than by the treatments or time. This is evident in the heatmap (Figure 5), which shows higher relative abundance of the mycorrhizal genus Elaphomyces in forest block 3 and of the non-mycorrhizal genus Archaerhizomyces in forest block 2 compared to the other forest blocks. At forest block 2, Archaerhizomyces was typically found in plots at ambient $\mathrm{pH}$. We previously found that Archaerhizomyces was a significant indicator of ambient $\mathrm{pH}$ plots (including the same ones in forest block 2) as part of a larger study [26]. In a recent study by Pinto-Figueroa [74], Archaerhizomyces relative abundance was influenced by a number of climate and edaphic properties. In the current study, the climatic conditions were consistent among our forest blocks, as they were all located at a similar latitude (see glaciated sites of Table 1 in DeForest et al. [32]) and it is difficult to discern if edaphic differences between the forest blocks were influencing the relative abundance of Archaerhizomyces since similar soil characteristics were not measured. However, 
it is plausible that soil $\mathrm{pH}$ may interact with other soil properties to influence the distribution of this largely uncultured but widespread fungal genus and future studies could help to disentangle these. We have previously documented that the forest blocks differ in their basal area of tree genera (see glaciated sites of Table 1 in DeForest et al. [32]), with Acer spp. representing over 68\% of the total basal area in forest block 2 compared to around 30\% in the other forest blocks and Fagus spp. (primarily F. grandifolia) representing over $21 \%$ of the total basal area in forest block 3 , compared to less than $6 \%$ in the other forest blocks. These changes in tree dominance could be influencing the fungal taxa at each site. For example, the low relative abundance of ectomycorrhizal fungal sequences in forest block 2 (Figure S1) could be related to the dominance of Acer trees, as these trees form relationships with arbuscular mycorrhizal fungi, while ectomycorrhizal-associated tree species, such as those in the Quercus and Fagus genera, were in low abundance (16.1\% and 5.6\% of total basal area, respectively; see DeForest et al. [32]). Plant host [75-77] and microsite variability [78] are important drivers of fungal community structure and diversity, especially for plant-associated fungi. Our data suggest that forest block was the most important factor influencing fungal community composition, which is similar to other multi-year studies on fungal community structure [79]. Thus, the current study builds on the literature showing that fungal communities in forests are structured largely by the availability of suitable plant hosts and high spatial heterogeneity at small scales, such as the stand level (reviewed by Baldrian [80]).

\subsection{Bacterial Community Response to $\mathrm{pH}$ Treatment}

Similar to our results with fungal communities, bacterial communities were also affected by elevating $\mathrm{pH}$, which is consistent with many other studies that have observed an effect of soil $\mathrm{pH}$ on bacterial community structure (e.g., $[21,23,25,81]$ ). In the current study, the taxa that responded to elevated soil $\mathrm{pH}$ are generally in agreement with Lauber et al. [21] where the relative abundance of Acidobacteria was higher at low $\mathrm{pH}$ conditions (consistent with Acidobacteriaceae and Koribacteraceae OTUs of the heat map; Figure 3). It should be noted that although Rousk et al. [23] found that some Acidobacteria subgroups were more abundant at low $\mathrm{pH}$, others were more abundant at elevated $\mathrm{pH}$, including subgroup 2. This could explain the higher relative abundance at elevated soil $\mathrm{pH}$ we found of the OTU matching with the Acidobacteria order Ellin6513, which is an undescribed taxa in subdivision 2 seen during the September sampling (see Figure 3). Although Lauber et al. [21] did not show clear effects of $\mathrm{pH}$ on Alphaproteobacteria, we found higher relative abundance of the genera Rhodoplanes and Bradyrhizobium in elevated pH plots at different time points (see Figure 3). This is similar to Rousk et al. [23] who found an increase in relative abundance of proteobacterial groups with increasing soil $\mathrm{pH}$ and Bartram et al. [82] who found a number of bacterial genera within the Alphaproteobacteria associated with neutral soil $\mathrm{pH}$, including Rhodoplanes and another rhizobial genus (although from a separate family), Mesorhizobium. It has been shown that Alphaproteobacteria are associated with $\mathrm{C}$ availability [83], which could explain the temporal variation associated with $\mathrm{pH}$ treatment for Rhodoplanes and Bradyrhizobium, which were relatively higher in September and July/November, respectively. Thus, these genera increased in relative abundance primarily during the growing season when plants are providing photosynthates for their mutualists, like nitrogen-fixing rhizobia.

\subsection{Microbial Community Response to P Treatment}

The plots of the current study were also manipulated to elevated soil $P_{i}$ availability and the effects of this elevation on microbial communities in forests are still not well understood. We found that fungal community response to $\mathrm{P}$ addition was not strong, with no effect of $\mathrm{P}$ addition on either fungal or bacterial community structure. Experimental addition of P in plots at Hubbard Brook Experimental Forest found few effects of $\mathrm{P}$ addition on fungal biomass but overall microbial community composition did change in $\mathrm{P}$ addition plots relative to control plots [84]. Forests in southern China showed variable responses to $P$ addition, with fungal biomass increasing and microbial community structure changing in response to $\mathrm{P}$ addition in old-growth evergreen forest plots, whereas microbial 
communities and biomass in pine and mixed broadleaf forests showed no response to $\mathrm{P}$ addition [85]. In a meta-analysis of field studies, Treseder [86] found some support for P effects on mycorrhizal fungal communities, but the effects varied among studies. It should be noted that only two studies examining ectomycorrhizal fungal communities and P addition experiments were included in Treseder [86], highlighting the general lack of studies exploring $\mathrm{P}$ effects on ectomycorrhizal fungi of forests. In our previous work, we found significant correlations between available forms of soil $\mathrm{P}$, specifically $\mathrm{P}_{\mathrm{O}}$, and ectomycorrhizal community structure in an old growth beech maple forest, but this correlation was seasonally dependent and evident only during late summer sampling [18]. We suggest that the weak effect of TSP application on fungal communities in the current study could be tied to microsite variation in resource availability. For example, in an old growth forest where fungal communities were correlated with soil $\mathrm{P}$, it was site location that was the largest factor explaining variation in these fungal communities, suggesting that microsite variation in soil $\mathrm{P}$ was related to fungal community structure [78]. The current study did show significant interactions for soil $\mathrm{pH}$ and $\mathrm{P}$ treatments for the relative abundance of saprotrophic and ERM fungi (a group known to degrade organic material [87]; Figure 6B,C), suggesting that alleviating both soil acidity and P limitation together could increase the abundance of these functional groups. However, multiple comparisons showed no significant differences between any of the individual treatments, indicating that the effects of $P_{i}$ manipulation overall on fungi were weak. Bacterial communities in the current study responded similarly to fungal communities to $\mathrm{P}$ addition with no changes in community structure. The consistent response of bacteria and fungi to changes in soil $\mathrm{P}$ is a result not unlike that of Liu et al. [85], in that both fungal and bacterial biomass responded similarly to $\mathrm{P}$ addition in old growth evergreen forests. Groffman and Fisk [84] saw no effect of $\mathrm{P}$ addition on microbial biomass in a temperate hardwood forest, although $\mathrm{P}$ addition did alter the overall microbial community structure compared to control plots.

\subsection{Summary}

In summary, we found that both bacterial and fungal communities responded to changes in soil $\mathrm{pH}$ within our temperate forests and that these changes were generally not influenced by the season of sampling. One exception to this was the relative abundance two genera of Acidobacteria, which increased at higher $\mathrm{pH}$ primarily during the growing season. Contrary to our hypotheses, we found no effect of changing $\mathrm{P}_{\mathrm{i}}$ availability on microbial community structure. However, we did find a strong influence of site on fungal communities. Our data are consistent with a number of previous investigations showing soil $\mathrm{pH}$ to have a strong effect on structuring microbial communities and that the heterogeneity inherent of many forests is a potentially strong driver of soil fungal community composition in particular.

Supplementary Materials: The following are available online at http://www.mdpi.com/2076-2607/8/1/1/s1, Figure S1: Relative sequence numbers of saprotrophic, ectomycorrhizal, and ericoid mycorrhizal fungi in each forest block.

Author Contributions: Conceptualization, D.J.B., L.A.K., and S.R.C.-K.; methodology, all authors; software, K.P.C.; validation, all authors; formal analysis, S.R.C.-K.; investigation, K.P.C.; resources, D.J.B.; data curation, K.P.C.; writing-original draft preparation, D.J.B. and S.R.C.-K.; writing-review and editing, all authors; visualization, S.R.C.-K.; supervision, D.J.B.; project administration, all authors; funding acquisition, D.J.B. All authors have read and agreed to the published version of the manuscript.

Funding: This research was funded by the National Science Foundation, grant number DEB-0918167, the Holden Arboretum Trust, the Corning Institute for Education and Research, and the R. Henry Norweb, Jr. Fellowship for Scientific Research in Horticulture. The APC was funded by the Holden Arboretum Trust and the Corning Institute for Education and Research.

Acknowledgments: The authors thank Charlotte Hewins, Jared DeForest and Kurt Smemo.

Conflicts of Interest: The authors declare no conflict of interest. The funders had no role in the design of the study; in the collection, analyses, or interpretation of data; in the writing of the manuscript, or in the decision to publish the results. 


\section{References}

1. Pan, Y.; Birdsey, R.A.; Phillips, O.L.; Jackson, R.B. The structure, distribution, and biomass of the world's forests. Annu. Rev. Ecol. Evol. Syst. 2013, 44, 593-622. [CrossRef]

2. Bellassen, V.; Luyssaert, S. Carbon sequenstration: Managing forests in uncertain times. Nature 2014, 506, 153-155. [CrossRef] [PubMed]

3. McKinley, D.C.; Ryan, M.G.; Birdsey, R.A.; Giardina, C.P.; Harmon, M.E.; Heath, L.S.; Houghton, R.A.; Jackson, R.B.; Morrison, J.F.; Murray, B.C.; et al. A synthesis of current knowledge on forests and carbon storage in the United States. Ecol. Appl. 2011, 21, 1902-1924. [CrossRef] [PubMed]

4. Andren, H. Effects of habitat fragmentation on birds and mammals in landscapes with different proportions of suitable habitat: A review. Oikos 1994, 71, 355-366. [CrossRef]

5. Dupouey, J.-L.; Dambrine, E.; Laffite, J.D.; Moares, C. Irreversible impact of past land use on forest soils and biodiversity. Ecology 2002, 83, 2978-2984. [CrossRef]

6. Johnson, N.M.; Driscoll, C.T.; Eaton, J.S.; Likens, G.E.; McDowell, W.H. 'Acid-Rain', dissolved aluminum and chemical weathering at the Hubbard Brook Experimental Forest, New Hampshire. Geochim. Cosmochim. Acta 1981, 45, 1421-1437. [CrossRef]

7. Lovett, G.M.; Goodale, C.L. A new conceptual model of nitrogen saturation based on experimental nitrogen addition to an oak forest. Ecosystems 2011, 14, 615-631. [CrossRef]

8. USDA Forest Service. U.S. Forest Facts and Historical Trends (FS-696); U.S. Department of Agriculture, Forest Service: Washington, DC, USA, 2001.

9. Aber, J.D.; Goodale, C.L.; Ollinger, S.V.; Smith, M.-L.; Magill, A.H.; Martin, M.E.; Hallett, R.A.; Stoddard, J.L. Is nitrogen deposition altering the nitrogen status of northeastern forests? BioScience 2003, 53, 375-389. [CrossRef]

10. Vitousek, P.M.; Farrington, H. Nutrient limitation and soil development: Experimental test of a biogeochemical theory. Biogeochemistry 1997, 37, 63-75. [CrossRef]

11. Goldberg, S.; Davis, J.A.; Hem, J.D. The surface chemistry of aluminum oxides and hydroxides. In The Environmental Chemistry of Aluminum; Sposito, G., Ed.; CRC Lewis Publishers: Boca Raton, FL, USA, 1996; pp. 271-331.

12. Booth, I.R. Regulation of cytoplasmic pH in bacteria. Microbiol. Rev. 1985, 49, 359-378.

13. Quivey, R.G., Jr.; Faustoferri, R.; Monahan, K.; Marquis, R. Shifts in membrane fatty acid profiles associated with acid adaptation of Streptococcus mutans. FEMS Microbiol. Lett. 2000, 189, 89-92. [CrossRef] [PubMed]

14. McGill, W.; Cole, C. Comparative aspects of cycling of organic C, N, S, and P through soil organic matter. Geoderma 1981, 26, 267-286. [CrossRef]

15. Olander, L.P.; Vitousek, P.M. Biological and geochemical sinks for phosphorus in soil from a wet tropical forest. Ecosystems 2004, 7, 404-419. [CrossRef]

16. Traina, S.J.; Sposito, G.; Hesterberg, D.; Kafkafi, U. Effects of pH and organic acids on ortho-phosphate solubility in an acidic, montmorillonitic soil. Soil Sci. Soc. Am. J. 1986, 50, 45-52. [CrossRef]

17. Hartman, W.H.; Richardson, C.J. Differential nutrient limitation of soil microbial biomass and metaboloic quotients (qCO2): Is there a biological stoichiometry of soil microbes? PLoS ONE 2013, 8, e57127. [CrossRef] [PubMed]

18. Burke, D.J.; López-Gutiérrez, J.C.; Smemo, K.A.; Chan, C.R. Vegetation and soil environment influence the spatial distribution of root-associated fungi in a mature beech-maple forest. Appl. Env. Microbiol. 2009, 75, 7639-7648. [CrossRef]

19. DeForest, J.L.; Scott, L.B. Available organic soil phosphorus has in important influence on microbial community composition. Soil Sci. Soc. Am. J. 2010, 74, 2059-2066. [CrossRef]

20. Kluber, L.A.; Carrino-Kyker, S.R.; Coyle, K.P.; DeForest, J.L.; Hewins, C.R.; Shaw, A.N.; Smemo, K.A.; Burke, D.J. Mycorrhizal response to experimental $\mathrm{pH}$ and $\mathrm{P}$ manipulation in acidic hardwood forests. PLoS ONE 2012, 7, e48946. [CrossRef]

21. Lauber, C.L.; Hamady, M.; Knight, R.; Fierer, N. Pyrosequencing-based assessment of soil pH as a predictor of soil bacterial community structure at the continental scale. Appl. Environ. Microbiol. 2009, 75, 5111-5120. [CrossRef] 
22. Morris, M.H.; Smith, M.E.; Rizzo, D.M.; Rejmánek, M.; Bledsoe, C.S. Contrasting ectomycorrhizal fungal communities on the roots of co-occurring oaks (Quercus spp.) in a California woodland. New Phytol. 2008, 178, 167-176. [CrossRef]

23. Rousk, J.; Bååth, E.; Brookes, P.C.; Lauber, C.L.; Lozupone, C.; Caporaso, J.G.; Knight, R.; Fierer, N. Soil bacterial and fungal communities across a pH gradient in an arable soil. ISME J. 2010, 4, 1340-1351. [CrossRef] [PubMed]

24. Bååth, E.; Anderson, T.H. Comparison of soil fungal/bacterial ratios in a pH gradient using physiological and PLFA-based techniques. Soil Biol. Biochem. 2003, 35, 955-963. [CrossRef]

25. Fierer, N.; Jackson, R.B. The diversity and biogeography of soil bacterial communities. Proc. Natl. Acad. Sci. USA 2006, 103, 626-631. [CrossRef] [PubMed]

26. Carrino-Kyker, S.R.; Kluber, L.A.; Petersen, S.M.; Coyle, K.P.; Hewins, C.R.; DeForest, J.L.; Smemo, K.A.; Burke, D.J. Mycorrhizal fungal communities respond to experimental elevation of soil $\mathrm{pH}$ and $\mathrm{P}$ availability in temperate hardwood forests. FEMS Microbiol. Ecol. 2016, 92, fiw024. [CrossRef] [PubMed]

27. Fiorentino, I.; Fahey, T.J.; Groffman, P.M.; Driscoll, C.T.; Eagar, C.; Siccama, T.G. Initial responses of phosphorus biogeochemistry to calcium addition in a northern hardwood forest ecosystem. Can. J. Res. 2003, 33, 1864-1873. [CrossRef]

28. Gress, S.E.; Nichols, T.D.; Northcraft, C.C.; Peterjohn, W.T. Nutrient limitation in soils exhibiting differing nitrogen availabilities: What lies beyond nitrogen saturation? Ecology 2007, 88, 119-130. [CrossRef]

29. Bardgett, R.D.; Bowman, W.D.; Kaufmann, R.; Schmidt, S.K. A temporal approach to linking aboveground and belowground ecology. Trends Ecol. Evol. 2005, 20, 634-641. [CrossRef]

30. Kaiser, C.; Koranda, M.; Kitzler, B.; Fuchsleuger, L.; Schnecker, J.; Schweiger, P.; Rasche, F.; Zechmeister-Boltenstern, S.; Sessitsch, A.; Richter, A. Belowground carbon allocation by trees drives seasonal patterns of extracellular enzyme activities by altering microbial community composition in a beech forest soil. New Phytol. 2010, 187, 843-858. [CrossRef]

31. Merino, C.; Nannipieri, P.; Matus, F. Soil carbon controlled by plant, microorganisms and mineralogy interactions. J. Soil Sci. Plant Nutr. 2015, 15, 321-332. [CrossRef]

32. DeForest, J.L.; Smemo, K.A.; Burke, D.J.; Elliott, H.L.; Becker, J.C. Soil microbial responses to elevated phosphorus and $\mathrm{pH}$ in acidic temperate deciduous forests. Biogeochemistry 2012, 109, 189-202. [CrossRef]

33. Maraun, M.; Scheu, S. Changes in microbial biomass, respiration and nutrient status of beech (Fagus sylvatica) leaf litter processed by millipedes (Glomeris marginata). Oecologia 1996, 107, 131-140. [CrossRef] [PubMed]

34. Gardes, M.; Bruns, T. ITS primers with enhanced specificity for basidiomycetes-application to the identification of mycorrhizae and rusts. Mol. Ecol. 1993, 2, 113-118. [CrossRef] [PubMed]

35. White, T.J.; Bruns, T.D.; Lee, S.B.; Taylor, J.W. Amplification and direct sequencing of fungal ribosomal RNA genes for phylogenetics. In PCR Protocols: A Guide to Methods and Applications; Innis, M.A., Gelfand, D.H., Sninsky, J.J., White, T.J., Eds.; Academic Press: New York, NY, USA, 1990; pp. 315-322.

36. Buée, M.; Reich, M.; Murat, C.; Morin, E.; Nilsson, R.H.; Uroz, S.; Martin, F. 454 Pyrosequencing analyses of forest soils reveal an unexpectedly high fungal diversity. New Phytol. 2009, 184, 449-456. [CrossRef] [PubMed]

37. Fierer, N.; Hamady, M.; Lauber, C.L.; Knight, R. The influence of sex, handedness, and washing on the diversity of hand surface bacteria. Proc. Natl. Acad. Sci. USA 2008, 105, 17994-17999. [CrossRef] [PubMed]

38. Blankenberg, D.; Von Kuster, G.; Coraor, N.; Ananda, G.; Lazarus, R.; Mangan, M.; Nekrutenko, A.; Taylor, J. Galaxy: A web-based genome analysis tool for experimentalists. Curr. Protoc. Mol. Biol. 2010, 19, 1-21. [CrossRef] [PubMed]

39. Giardine, B.; Riemer, C.; Hardison, R.C.; Burhans, R.; Elnitski, L.; Shah, P.; Zhang, Y.; Blankenberg, D.; Albert, I.; Taylor, J.; et al. Galaxy: A platform for interactive large-scale genome analysis. Genome Res. 2005, 15, 1451-1455. [CrossRef]

40. Goecks, J.; Nekrutenko, A.; Taylor, J.; Galaxy Team. Galaxy: A comprehensive approach for supporting accessible, reproducible, and transparent computational research in the life sciences. Genome Biol. 2010, 11, R86. [CrossRef]

41. Edgar, R.C. UPARSE: Highly accurate OTU sequences from microbial amplicon reads. Nat. Methods 2013, 10, 996-998. [CrossRef]

42. Edgar, R.C. Search and clustering orders of magnitude faster than BLAST. Bioinformatics 2010, 26, $2460-2461$. [CrossRef] 
43. Edgar, R.C.; Haas, B.J.; Clemente, J.C.; Quince, C.; Knight, R. UCHIME improves sensitivity and speed of chimera detection. Bioinformatics 2011, 27, 2194-2200. [CrossRef]

44. Abarenkov, K.; Nilsson, R.H.; Larsson, K.-H.; Alexander, I.J.; Eberhardt, U.; Erland, S.; Høiland, K.; Kjøller, R.; Larsson, E.; Pennanen, T.; et al. The UNITE database for molecular identification of fungi-Recent updates and future perspectives. New Phytol. 2010, 186, 281-285. [CrossRef] [PubMed]

45. Kõljalg, U.; Nilsson, R.H.; Abarenkov, K.; Tedersoo, L.; Taylor, A.F.S.; Bahram, M.; Bates, S.T.; Bruns, T.D.; Bengtsson-Palme, J.; Callaghan, T.M.; et al. Towards a unified paradigm for sequence-based identification of fungi. Mol. Ecol. 2013, 22, 5271-5277. [CrossRef] [PubMed]

46. Reddy, T.B.K.; Thomas, A.D.; Stamatis, D.; Bertsch, J.; Isbandi, M.; Jansson, J.; Mallajosyula, J.; Pagani, I.; Lobos, E.A.; Kyrpides, N.C. The Genomes OnLine Database (GOLD) v.5: A metadata management system based on a four level (meta)genome project classification. Nucleic Acids Res. 2015, 43, 1099-1106. [CrossRef] [PubMed]

47. Caporaso, J.G.; Kuczynski, J.; Stombaugh, J.; Bittinger, K.; Bushman, F.D.; Costello, E.K.; Fierer, N.; Peña, A.G.; Goodrich, J.K.; Gordon, J.I.; et al. QIIME allows analysis of high-throughput community sequencing data. Nat. Methods 2010, 7, 335-336. [CrossRef]

48. Altschul, S.; Gish, W.; Miller, W.; Myers, E.W.; Lipman, D.J. Basic local alignment search tool. J. Mol. Biol. 1990, 215, 403-410. [CrossRef]

49. McDonald, D.; Price, M.; Goodrich, J.; Nawrocki, E.P.; DeSantis, T.Z.; Probst, A.; Andersen, G.L.; Knight, R.; Hugenholtz, P. An improved Greengenes taxonomy with explicit ranks for ecological and evolutionary analyses of bacteria and archaea. ISME J. 2012, 6, 610-618. [CrossRef]

50. Werner, J.; Koren, O.; Hugenholtz, P.; DeSantis, T.Z.; Walters, W.A.; Caporaso, J.G.; Angenent, L.T.; Knight, R.; Ley, R.E. Impact of training sets on classification of high-throughput bacterial 16S rRNA gene surveys. ISME J. 2012, 6, 94-103. [CrossRef]

51. Dickie, I. Insidious effects of sequencing errors on perceived diversity in molecular surveys. New Phytol. 2010, 188, 916-918. [CrossRef]

52. Oksanen, J.; Blanchet, F.G.; Kindt, R.; Legendre, P.; Minchin, P.R.; O’Hara, R.B.; Simpson, G.L.; Solymos, P.; Stevens, M.H.H.; Wagner, H. Vegan: Community Ecology Package, v2.5.5. 2013. Available online: http://CRAN.R-project.org/package=vegan.

53. R Development Core Team. R: A Language and Environment for Statistical Computing; R Foundation for Statistical Computing: Vienna, Austria, 2013; Available online: http://www.R-project.org/.

54. Robinson, M.D.; McCarthy, D.J.; Smyth, G.K. edgeR: A Bioconductor package for differential expression analysis of digital gene expression data. Bioinformatics 2010, 26, 139-140. [CrossRef]

55. McCarthy, D.J.; Chen, Y.; Smyth, G.K. Differential expression analysis of multifactor RNA-Seq experiments with respect to biological variation. Nucleic Acids Res. 2012, 40, 4288-4297. [CrossRef]

56. McMurdie, P.J.; Holmes, S. Waste not, want not: Why rarefying microbiome data is inadmissible. PLoS Comput. Biol. 2014, 10, e1003531. [CrossRef] [PubMed]

57. Ploner, A. Heatplus: Heatmaps with Row and/or Column Covariates and Colored Clusters, v2.28.0. 2019. Available online: https://github.com/alexploner/Heatplus.

58. Nguyen, N.H.; Song, Z.; Bates, S.T.; Branco, S.; Tedersoo, L.; Menke, J.; Schilling, J.S.; Kennedy, P.G. FUNGuild: An open annotation tool for parsing fungal community datasets by ecological guild. Fungal Ecol. 2015, 20, 241-248. [CrossRef]

59. Pinheiro, J.; Bates, D.; DebRoy, S.; Sarkar, D.; R Core Team. Nlme: Linear and Nonlinear Mixed Effects Models, v3.1.137. 2019. Available online: https://CRAN.R-project.org/package=nlme.

60. Hothorn, T.; Bretz, F.; Westfall, P. Simultaneous inference in general parametric models. Biom. J. 2008, 50, 346-363. [CrossRef] [PubMed]

61. Wickham, H. ggplot2: Elegant Graphics for Data Analysis; Springer: New York, NY, USA, 2016.

62. McArthur, J.V. Microbial Ecology: An Evolutionary Approach; Academic Press: San Diego, CA, USA, 2006.

63. Stumm, W.; Morgan, J.J. Aquatic Chemistry, Chemical Equilibria and Rates in Natural Waters, 3rd ed.; John Wiley \& Sons, Inc.: New York, NY, USA, 1996.

64. Walker, L.; Syers, J. The fate of phosphorus during pedogenesis. Geoderma 1976, 15, 1-19. [CrossRef]

65. Madigan, M.T.; Martinko, J.M.; Parker, J. (Eds.) Brock Biology of Microorganisms; Pearson Education, Inc.: Upper Saddle River, NJ, USA, 2003. 
66. Erland, S.; Söderström, B. Effects of liming on ectomycorrhizal fungi infecting Pinus sylvestris L. I. mycorrhizal infection in limed humus in the laboratory and isolation of fungi from mycorrhizal roots. New Phytol. 1990, 115, 675-682. [CrossRef]

67. Lehto, T. Effects of liming and boron fertilization on mycorrhizas of Picea abies. Plant Soil 1994, 163, 65-68. [CrossRef]

68. Rineau, F.; Maurice, J.-P.; Nys, C.; Voiry, H.; Garbaye, J. Forest liming durably impact the communities of ectomycorrhizas and fungal epigeous fruiting bodies. Ann. Sci. 2010, 67, 110. [CrossRef]

69. Wubet, T.; Christ, S.; Schöning, I.; Boch, S.; Gawlich, M.; Schnabel, B.; Fischer, M.; Buscot, F. Differences in soil fungal communities between European beech (Fagus sylvatica L.) dominated forests are related to soil and understory vegetation. PLOS ONE 2012, 7, e47500. [CrossRef]

70. Kottke, I.; Weber, R.; Ritter, T.; Oberwinkler, F. Activity of mycorrhizas and health status of trees on diverse forest stands in West Germany. In Forest Decline in the Atlantic and Pacific Regions; Hüttl, R.F., Mueller-Dombois, D., Eds.; Springer: Berlin, Germany, 1993; pp. 189-201.

71. Bödeker, I.T.M.; Lindahl, B.D.; Olson, A.; Clemmensen, K.E. Mycorrhizal and saprotrophic fungal guilds compete for the same organic substrates but affect decomposition differently. Funct. Ecol. 2016, 30, 1967-1978. [CrossRef]

72. Crowther, T.W.; Boddy, L.; Jones, T.H. Functional and ecological consequences of saprotrophic fungus-grazer interactions. ISME J. 2012, 6, 1992-2001. [CrossRef]

73. Izzo, A.; Agbowo, J.; Bruns, T.D. Detection of plot-level changes in ectomycorrhizal communities across years in an old-growth mixed-conifer forest. New Phytol. 2005, 166, 619-629. [CrossRef] [PubMed]

74. Pinto-Figueroa, E.A.; Seddon, E.; Yashiro, E.; Buri, A.; Niculita-Hirzel, H.; van der Meer, J.R.; Guisan, A. Archaeorhizomycetes spatial distribution in soils along wide elevational and environmental gradients reveal co-abundance patterns with other fungal saprobes and potential weathering capacities. Front. Microbiol. 2019, 10, 656. [CrossRef] [PubMed]

75. Saitta, A.; Anslan, S.; Bahram, M.; Brocca, L.; Tedersoo, L. Tree species identity and diversity drive fungal richness and community composition along an elevational gradient in a Mediterranean ecosystem. Mycorrhiza 2018, 28, 39-47. [CrossRef] [PubMed]

76. Tedersoo, L.; Mett, M.; Ishida, T.A.; Bahram, M. Phylogenetic relationships among host plants explain differences in fungal species richness and community composition in ectomycorrhizal symbiosis. New Phytol. 2013, 199, 822-831. [CrossRef] [PubMed]

77. U’Ren, J.M.; Lutzoni, F.; Miadlikowska, J.; Zimmerman, N.B.; Carbone, I.; May, G.; Arnold, A.E. Host availability drives distributions of fungal endophytes in the imperiled boreal realm. Nat. Ecol. Evol. 2019, 3, 1430-1437. [CrossRef] [PubMed]

78. Tedersoo, L.; Suvi, T.; Jairus, T.; Kõljalg, U. Forest microsite effects on community composition of ectomycorrhizal fungi on seedlings of Picea albies and Betula pendula. Environ. Microbiol. 2008, 10, 1189-1201. [CrossRef]

79. Burke, D.J. Effects of annual and inter-annual environmental variability on soil fungi associated with an old-growth, temperate hardwood forest. FEMS Microbiol. Ecol. 2015, 91, fiv053. [CrossRef]

80. Baldrian, P. Forest microbiome: Diversity, complexity and dynamics. FEMS Microbiol. Rev. 2017, 41, $109-130$. [CrossRef]

81. Hackl, E.; Zechmeister-Boltenstern, S.; Bodrossy, L.; Sessitsch, A. Comparison of diversities and compositions of bacterial populations inhabiting natural forest soils. Appl. Environ. Microbiol. 2004, 70, 5057-5065. [CrossRef]

82. Bartram, A.K.; Jiang, X.; Lynch, M.D.J.; Masella, A.P.; Nicol, G.W.; Dushoff, J.; Neufeld, J.D. Exploring links between $\mathrm{pH}$ and bacterial community composition in soils from the Craibstone Experimental Farm. FEMS Microbiol. Ecol. 2013, 87, 403-415. [CrossRef]

83. Fierer, N.; Bradford, M.A.; Jackson, R.B. Toward an ecological classification of soil bacteria. Ecology 2007, 88, 1354-1364. [CrossRef] [PubMed]

84. Groffman, P.M.; Fisk, M.C. Phosphate additions have no effect on microbial biomass and activity in a northern hardwood forest. Soil Biol. Biochem. 2011, 43, 2441-2449. [CrossRef]

85. Liu, L.; Gundersen, P.; Zhang, T.; Mo, J. Effects of phosphorus addition on soil micorbial biomass and community composition in three forest types in tropical China. Soil Biol. Biochem. 2012, 44, 31-38. [CrossRef] 
86. Treseder, K.K. A meta-analysis of mycorrhizal responses to nitrogen, phosphorus, and atmospheric $\mathrm{CO}_{2}$ in field studies. New Phytol. 2004, 164, 347-355. [CrossRef]

87. Martino, E.; Morin, E.; Greler, G.-A.; Kuo, A.; Kohler, A.; Daghino, S.; Barry, K.W.; Cichocki, N.; Clum, A.; Dockter, R.B.; et al. Comparative genomics and transcriptomics depict ericoid mycorrhizal fungi as versatile saprotrophs and plant mutualists. New Phytol. 2018, 217, 1213-1229. [CrossRef]

(C) 2019 by the authors. Licensee MDPI, Basel, Switzerland. This article is an open access article distributed under the terms and conditions of the Creative Commons Attribution (CC BY) license (http://creativecommons.org/licenses/by/4.0/). 